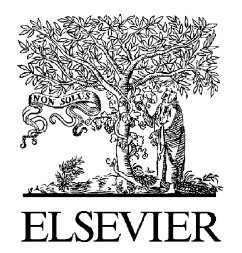

\title{
EDITORIAL
}

\section{The development of the Primary Care Respiratory Journal}

Our more astute readers will have noticed by now, halfway through the year, that they have received three issues already. The establishment of a bi-monthly journal is another step in the development of the Primary Care Respiratory Journal (PCRJ), one which exemplifies the increasing importance of primary care research in the management of respiratory disease. We felt it appropriate to mark this with an assessment of how far the journal has come over the last ten years, and to share our ideas for further development.

The PCRJ is the journal of the Enereal Eactice Airways Group (GPIA G), fermerty the 'GPs tin

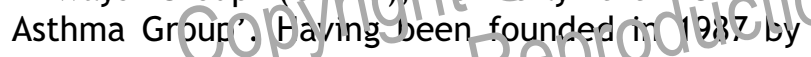
a group of general practitio rers (f) ws) who had an interest in respiratory disease, the GPIAG has grown enormously in its scope and influence, is now a registered charity, is one of the foremost primary care special interest groups in the UK, and is well known and respected internationally. Over the last four years, the PCRJ has been the official journal of the International Primary Care Respiratory Group (IPCRG; www.theipcrg.org), an organisation that is thriving and ready to host its Third World Conference in Oslo in 2006 [1]; this also emphasises the international credentials and importance of the PCRJ.

The development of the PCRJ has mirrored that of the GPIAG. Up to 1996, 'Asthma in General Practice', the early title of the journal, was a twice-yearly GPIAG newsletter. A new editorial team was assembled in 1997 with very specific aims; to produce a journal relevant to all those working in primary care with an interest in respiratory disease, to attract high quality research and audit papers for publication, to establish a process for high quality peer review, and to stimulate and encourage young researchers through mentorship and publication of pilot studies and ideas for research [2]. Two issues of the journal were published in 1997 as Volume 5, and the second issue that year celebrated the 10th anniversary of the GPIAG. In 1998 we made the leap to three issues a year, and two years later the journal title was changed to its preselits "Primary Care Respiratory Journal', fus lemplasising the role of primary cale in managing thronic obstructive pulmonary disease (CoPd). rhinitis, allergic disease, and many other respiratory diseases in addition to asthma. In 2002, we increased to four issues a year, exceeding 100 pages in a volume for the first time [3]. Now, in 2005, the PCRJ is a bi-monthly journal, with six issues a year, and previous issues of the journal, from Volume 5 to Volume 12, can be viewed on-line via the GPIAG web-site at http: / / www.gpiag.org/journ/issues. php.

In the late 1990's, the journal was published by Strategic Medical Publishing (SMP), and then for several years we published the journal ourselves in the GPIAG office. After considerable deliberation, 18 months ago we entered into a publishing agreement with Elsevier, one of the biggest and most highly-regarded scientific publishing houses in the world. Elsevier started publishing the PCRJ with Volume 13 last year, and we continue to work with them to bring you the best possible quality journal we can.

Editorially, we hope that we have established a reputation for integrity and independence, coupled with rigorous high-quality peer review. We are enormously grateful to those expert clinicians throughout the world who referee papers for us 
so assiduously. The initial Editorial Board from 1997 is almost intact - John Haughney left the journal in order to be GPIAG chairman in 2000 and was replaced by Aziz Sheikh - and we have since expanded to include an International Editorial Board, whose membership comprises some of the most pre-eminent figures in primary care respiratory medicine throughout the world, almost all of whom are members of the GPIAG and IPCRG.

The number of papers submitted to the PCRJ has nearly trebled over the last two years; these have been from well-respected academics and clinicians, both from the UK and from abroad. This has enabled us to increase to six issues a year. In particular, we offer medical copy-editing in-house for first-time writers and for international authors whose first language is not English, which we believe is helpful in attracting international papers - thus allowing the journal to fulfil its role as an international journal on behalf of the IPCRG.

Where do we go now? We will be seeking Medline listing soon, and we hope that, once this is achieved, the PCRJ will be an even more attractive option for authors. In accordance with our aim to facilitate practical application of research findings in primary care, we are increasingly linking guest editorial opinion with high quali $y$ reviews and original research, and wo $1: \sqrt{ } \in$ had several themed issues. W/ tontinue to publish news and information from the GPIAG, the Iit ClRG, and other relevant organisatior 3 , an 1 we offer a variety of mechanisms for publishing shorter work such as our Short Report section and our 'Stop, think' and 'Personal opinion' series'. We publish correspondence in both the paper- and web-based versions of the journal, and this is something we are very keen to develop. 'Fast-track' material can be published quickly, increasing the currency of both the Research and Letters sections of the journal. As from March 2005, the PCRJ has had the full facility for online submission and for author-tracking of a paper once it has been received (see http: / /www.ees.elsevier.com/pcrj). Increasing numbers of high quality paper submissions and financial subscriptions to the journal have further established the PCRJ as the pre-eminent journal for those involved in primary care respiratory medicine throughout the world.

At present, the paper version of the journal is available free of charge to members of the
GPIAG and is available by subscription for $€ 102$ to non-members - to subscribe, visit the website: http://www.intl.elsevierhealth.com/journals/ pcrj/. Currently, the IPCRG also purchases copies of the journal for distribution to its membership. The journal is available online via ScienceDirect (http://www.sciencedirect.com) to entitled institutional subscribers, and on a pay-per-use basis to individuals. Online abstracts of all papers published in the PCRJ are available free of charge at both ScienceDirect and http://www.thepcrj.com.

Thank you for your support of the journal, and we hope that you enjoy this issue. If you do, tell your colleagues; encourage them to subscribe and to look at previous issues, send us your papers, and write to us at publishing@gpiag.org so that we can publish your letters in the Letters section!

\section{Acknowledgement}

We are grateful to Leighton Chipperfield at Elsevier for his advice and clarification regarding the present subscription aranger $\in$ r $t$ : and online contact details for ti $E$ FSRJ

\section{Referauläs}

[1] International Primary Care Respiratory Group (IPCRG). Update, GPIAG/IPCRG News section. Prim Care Resp J 2005;14(2):112.

[2] Levy ML. The future of Asthma in General Practice. Asthma in General Practice [now Primary Care Respiratory Journal] 1997;5(1):2.

[3] Levy ML. (Editorial) In this issue...Prim Care Resp J 2002; 11(3): 81.

Mark L. Levy (Editor-in-Chief)*

Paul Stephenson (Deputy Editor)

Chris Griffiths (Assistant Editor)

Robert McKinley (Assistant Editor)

Aziz Sheikh (Assistant Editor)

Patricia Bryant (Publications Manager)

GPIAG, Smithy House, Waterbeck

Lockerbie DG 11 3EY, UK

*Corresponding author. Tel: +44 (0) 1461600639

fax: +44 (0) 1461207819

E-mail address: marklevy@animalswild.com

(M.L. Levy)

Available online at www.sciencedirect.com

science $\mathcal{d}$ direct. 